\title{
Is E-Learning that important? SMEs Training and Economic Performance
}

\author{
Shamim Akhtar (corresponding author) \\ School of Economics and Management \\ Xidian University Xian.Shaanxi, China \\ E-mail: Shamim462@gmail.com
}

Dr. Yanping Liu

School of Economics and Management

Xidian University Xian.Shaanxi, China

E-mail: Yanpingliu@xid.edo.cn

Youyuan Zheng

School of Economics and Management

Xidian University Xian.Shaanxi, China

E-mail: Zhengyouyuan@126.com

Received: Nov. 19, 2018 Accepted: Dec. 5, 2018 Online published: Dec. 18, 2018

doi:10.5296/jpag.v8i4.14066ＵRL: https://doi.org/10.5296/jpag.v8i4.14066

\begin{abstract}
Fronting stress from a progressively competitive business environment, enterprises have, over the years, employed trainings in order to have more efficient work force and also to enhance performance. The drive of this study is to ascertain different problems to e-learning that small and medium enterprises faced in their training process and attests, through a case study, how well e-learning could resolve some of many hitches identified. This study also identifies how e-learning can enhance small and medium sized enterprises performance.
\end{abstract}

Keywords: e-learning, SMEs, performance, training, barriers 


\section{Introduction}

Small and medium sized enterprises (SMEs) are reflected as basis of economic growth and are perceived as a significant segment for generating employment. The significance of mounting small and medium enterprises has been realized to contribute towards unified and advanced economic arrangement of economies Hussain et. al. (2007). Therefore, learning and training are realized dire to SMEs progression in many countries. E-learning offers various practical gains particularly for the situations, where traditional learning is excessively costly or time taking. Small and medium enterprises (SMEs) can exemplify one of such situations; generally workers in SMEs have very little time for the learning accessible and e-learning appears to be the perfect way out. Yet, research on e-learning in SMEs is pretty recent; quite little research work has been done. Furthermore, literature and practice emphasis tremendously on the large enterprises at the expense of small and medium sized enterprises (SMEs).

SMEs sector is deliberated as back bone of economy of Pakistan. SME sector shows vital role to improve economy and the solitary persistence in the times of poorer economic disorders. It is pretty fair to comment that the Pakistani economy is the economy of SMEs. Roughly this sector set up $90 \%$ of overall business sectors, 76 percent of total industrialized employment is shielded by this only sector. SMEs add $41 \%$ in the annual GDP of economy of Pakistan (SMEDA, 2010). SME segment in Pakistan further account for the employment creation of around 22 million people and give around $23 \%$ in the national industrial exports. Although SME sector have momentous role in the development of the economy, still this sector ignored in the country like Pakistan and has not appealed sufficient consideration from researcher's side. Entrepreneurs encounter many hitches which confine the long term sustainability and expansion of enterprises. Pakistani economy is considered among one of those economies where inflation rate is pretty high and the business productiveness is completely under the uncertainty. The rate of failure among SMEs development in the developing economies is more as compare to the developed ones. Thus, to grow an affluent economy, business sector principally, SMEs sector needs more attention. Furthermore, the supervisory strategies in Pakistan are conducive in nature; the Government policies are intensive largely, on the large scale firm's progress. Noticeably, it is apparent that there are numerous problems allied with the attainment of SMEs and the owners-managers need to update their workers.

It is therefore significant to know the problems attached with the learning and restricted productivity of SMEs, how and where such problems arise in the training process. It is also crucial to realize if e-learning could be answer of some problems SMEs encountered and how it can enhance economic performance and progress of SMEs. The drive of this research is three fold. First, after identifying the various steps of SMEs training process, grounded on a survey, we will conclude, over a case study, in what step Pakistani SMEs have faced hitches. Second is to determine if e-learning could resolve some of hitches known and how. Lastly, we will confirm how e-learning can boost economic performance and productivity of small and medium sized enterprises. 


\section{Theoretical Context}

The implementation of e-learning technology in order to train the employees and human resource improvement is swiftly rising in those of larger enterprises and slighter in case of small and medium sized enterprises (Beamish et al,. 2002; Misko et al,. 2004. The existing literature is converging, for the utmost part, on problems of finance and technological hitches Hall, B. and LeCavalier, J. (2000), while research on work place e-learning is believed to entail a better theoretical foundation (Daelen et al,. 2005), on those of various steps that process of training have in SMEs, wider conceptualization of the impact of e-learning on enterprises and its workforce Servage, L. (2005).

\section{Analysis of Training Needs}

The first step in training process is the training need analysis. It comprised of ascertaining list of training needs by using various activities (Brown et al,.2002; Cook, S. 2005a). This analysis must be done before developing training program in order to recognize particular training hitches, to get the assistance of management, to sort out data that will be helpful in the final evaluation and lastly, to confirm the costs and gains of the training (Brown et al,.2002). To ascertain the needs of training there are different techniques, methods and tools. Yet, referring to Bassi et al,. 1999b; Elbadri et al,. 2001; Sadler-Smith et al,. 1998, the commonly used techniques in the identification of business training needs are: the immediate boss notifies the need ( that's more often used informal technique according to Tyler, K. (1999) evaluation of performance, employee interviews, attitudinal observation, group consultations, surveys, business plan, abilities test and formal analysis of the needs of business. The causes for such selections are, among others, time, budget and affluence of use. After the completion of training needs analysis and when needs are determined, one can carry on in deciding the method of training, phase of process that also significant in learning consequences.

\section{Training Methods}

Training method definition suggested by (Laflamme, R.1999) the method that will be employed in order to diffuse the subject matter and to empower learning. They can be informal or formal (Kotey et al,. 2004; Tanova, C. and Nadiri, H. 2005) and they can also be gathered rendering to whether they are taken to be affirmative (seminars, lectures...) interrogative (computer centered training) or active (learning by doing, case study, one to one...).

It seems that large organizations mostly use formal methods of training than small and medium enterprises (SMEs) Tanova, C. and Nadiri, H. (2005).Seminars, conferences, mentoring (one to one) and short lectures given in classroom style are the methods of training considered most related and desired by the businesses. Literature has also established that internet is reflected as a very actual manner of giving information to different individuals, as much in SMEs rather larger organizations (Bassi et al,. 1999b; Elbadri et al,. 2001; Smith et al,. 1999; Lawless et al,. 2000).

Another study conducted by Lawless et al,. (2000) suggested that, 93\% of SMEs choose "one 
to one" training for instance the training directly presented to them by a trainer. Moreover, almost $70 \%$ of SMEs choose to get training on mandate instead of systematic scheduled.

The selection of the method of training must be made according to the objectives and needs of the training, the resources accessible, the style of learning of employees who will be trained and principles of learning. An approach that comprised of range of methods (various learning types), examples and tools has more chances of success Bassi et al,. 1999b; Elbadri et al,. 2001; Bassi et al,. 1999a; Garavaglia, P.L. (1993) for the reason that, as revealed by Fry, K. (2001), enterprises are made up of workforce whose experience and age group vary, and have diverse inclinations concerning to ways of learning and use of technology.

When method of training has been selected, next step is the selection of the tools which will be used in endowment of training course. The selection of good tools is also significant in the learning outcomes.

\section{Tools of Training}

Training tools are assistances to learning and provision for training (Laflamme, R.1999). They must be designated centered on principles for instance the level of stroke essential to the trainees and for the trainer, the interaction level among trainees and between them and the trainer, the affluence of creating and using the tool, the expense of production and use of the tool Mayo et al (1987), and the objectives of the training chased Savoie, A. (1987). The four broader sets are named as; auditory tools ( tape recorder), visual tools (notes; white board), interactive tools ( multimedia, computer) and audiovisual tools for instance film; slide show (Laflamme, R.1999).

Lastly, when all set with the selection of training method and the training tools, and training has been delivered then we can head towards the last stage of training named as training evaluation.

\section{Training Evaluation}

The evaluation comprised of different activities that gauge learning results and this, evaluated both with respect to training as the gains that derived by the businesses from (Brown et al,.2002), and making a decision on the offered training. Different models are there to evaluate the gains of training (Yin et al,. 1994), and training evaluation done on the different levels of training. However, the Kirkpatrick model is mostly used and considered appropriate method of training evaluation (Yin et al,.1994), Kirkpatrick model consists of different evaluation levels namely; reaction, learning, behavior and results.

Some other methods are also used to evaluate the training processes for instance according to the Garavaglia, P.L. (1993) businesses mostly used; supervisor's reports, questionnaires, surveys, action plan development, employee interviews, simulations, case studies observing employees and other real life situations.

Additionally, to analyze the business training processes, it is significant to know that in which stage of the process SMEs use e-learning and on what grounds. 


\section{Research Methods}

Specified the current level of acquaintance and understanding with respect to e-learning in case of small and medium enterprises, an exploratory and qualitative approach was deployed. The case study methodology is well adjusted in the situations in which theoretical argumentations are very little and the field experience is also partial Mittelstaedt, J.D., Harben, G.N. and Ward, W.A. (2003). A multiple- pot case study empowers one to comprehend the specific structure and progression of every firm with respect to e-learning. In total sixteen SMEs were studied located in the Punjab region of Pakistan. They were nominated to be appropriately efficacious (minimum 10 years in business) and demonstrative in with respect to size and industry, thus results can be well generalized. The SME Bank, Small and Medium Enterprise Development Authority Pakistan (SMEDAP), Pakistan Bureau of Statistics (PBS) and the State Bank of Pakistan (SBP) have demarcated SMEs in differently. General criteria to define SME in Pakistan lies on number of employees SE number of employees up to 50 and in case of ME 51-250 employees. Data were gathered by using semi structured type recorded interviews with the SME owner/manager or CEO and also with the human resource managers or the person who responsible for the training. The users of e-learning in four cases were also interviewed. After that transcripts of interview were analyzed and coded according to the recommendations of Miles et al.(1994). As mentioned in study outcomes, the studied firms ranged in size 50 to 250 employees and function in industries where technological strength diverges from low to high. Further, SMEs were reorganized in four different e-learning profiles of increasing strength, grounded on their state of knowledge and e-learning use (strong, average, weak, none).

\section{Study Findings}

The study presents that the process of training of SMEs consists the training need analysis, collection and deployment of tools and methods of training, along with training evaluation and that SMEs draw on mix of different training methods for the purpose of providing training to the employees and to enhance their economic performance and output. Study found that some of the SMEs use e-learning as the training method, yet some do not use e-learning at all as presented in the table 3. A through study on the SMEs revealed apprehension on e-learning and the use of e-learning empower us in achieving their degree of use. Exploration also make available for classifying the small and medium scaled enterprises into the four different profiles as users of e-learning. Some SMEs shows that they are greatly using e-learning those comes under profile "strong use" and some who employ quite a little (normal), some SMEs use e-learning very little (fragile) and those SMEs that don't use it at all categorized as "absence". 
Table1. Profiles of SMEs using E-Learning

\begin{tabular}{l|c|c|c|c}
\hline Features & Profile 1 & Profile 2 & Profile 3 & Profile 4 \\
& $(\boldsymbol{S}, \boldsymbol{I}, \boldsymbol{H}, \boldsymbol{R})$ & $(\boldsymbol{A}, \boldsymbol{M}, \boldsymbol{F} . \boldsymbol{Z})$ & $(\boldsymbol{O}, \boldsymbol{D}, \boldsymbol{K}, \boldsymbol{L})$ & $(\boldsymbol{P}, \boldsymbol{G}, \boldsymbol{N}, \boldsymbol{B})$ \\
\hline $\begin{array}{l}\text { Size } \\
\text { No. of }\end{array}$ & 150 to 250 & 90 to 180 & 100 to 230 & 45 to 200 \\
\hline $\begin{array}{l}\text { Employees } \\
\text { e-learning }\end{array}$ & Strong & Normal & Fragile & absence \\
\hline
\end{tabular}

The detailed examination of understudy SMEs empowers us to know what tools and methods of training they deploy and, the hitches faced and how e-learning can answer some of these problems.

Analysis of training needs, problems encountered and probable answers via e-learning

The in-depth analysis of SMEs, study findings and literature consensus on, that what diverges from SME to SME, is the level of formalization and the manner with which exploration conducted, and degree of superiority of the tools deployed as presented in table 2. In some situations the examination of needs of training is conducted with fewer tools in less appropriate manner. In other situations, however, the rigorous tools and extremely sophisticated manners are utilized. Mr.Ahsen the CEO from one of the studied SME delivers us with an example stating that "we have a Learning Management System (LMS)".

We witnessed those SMEs who make a great use of the e-learning and other technologies in overall, for instance SMEs from profile one (S, I, H and R), conduct more formalized and through need analysis. They use supplementary refined tools; even some of them use learning management system (LMS) software. Also they identify their needs of training earlier. The needs of the training are either noticed during hiring time of employees or categorically early in the process. CEO Ahsen provides us an example "The need analysis for training is performed when we recruit employees; analysis completed before they jump to work. We have LMS in our enterprise".

It also appears that such SMEs are more systematic and structured in a manner they examine their training needs. As they have a particular goal or the enterprise's objectives. It realizes that e-learning could answer some of the problems recognized during the need analysis stage. E-learning empowers SMEs to observe, when employing or pretty early in training process, the needs of training of their employees. Moreover, e-learning appears to have the probability to make sure the realization of company's objectives. 
Table 2. Formalization and Tools used to conduct Training need analysis

\begin{tabular}{|c|c|c|c|c|}
\hline Profiles & SMEs & Holistic & Formalization & Tools used \\
\hline \multirow{4}{*}{ 预 } & $\mathrm{S}$ & Yes & High & - $\quad$ Learning management system (LMS) \\
\hline & I & Yes & High & $\begin{array}{ll}\text { - } & \text { Performance evaluation } \\
\text { - } & \text { personal growth plans } \\
\text { - } & \text { Skill gap analysis } \\
\text { - } & \text { Industrial psychological tests } \\
\end{array}$ \\
\hline & $\mathrm{H}$ & Yes & High & $\begin{array}{ll}\text { - } & \text { Performance appraisal system } \\
\text { - } & \text { Need analysis of SMEs } \\
\text { - } & \text { Different softwares } \\
\end{array}$ \\
\hline & $\mathrm{R}$ & Yes & High & - Learning management system (LMS) \\
\hline \multirow{4}{*}{ 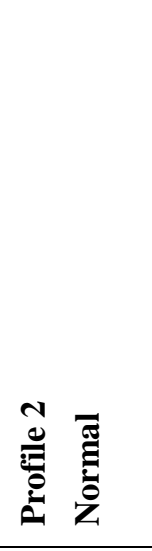 } & A & No & normal & $\begin{array}{ll}\text { - } & \text { External evaluation } \\
\text { - } & \text { Supervisor observes needs } \\
\end{array}$ \\
\hline & $\mathrm{M}$ & Yes & High & $\begin{array}{ll}\text { - } & \text { Skills analysis } \\
\text { - } & \text { Tasks analysis } \\
\text { - } & \text { observation } \\
\end{array}$ \\
\hline & $\mathrm{F}$ & No & normal & $\begin{array}{ll}\text { - } & \text { Database } \\
\text { - } & \text { Skills matrix } \\
\text { - } & \text { Tasks analysis } \\
\end{array}$ \\
\hline & $\mathrm{Z}$ & No & normal & $\begin{array}{ll}\text { - } & \text { Management by objectives } \\
\text { - } & \text { Skills matrix } \\
\end{array}$ \\
\hline \multirow[b]{4}{*}{ 总 } & $\mathrm{O}$ & Yes & poor & $\begin{array}{ll}\text { - } & \text { Tasks analysis } \\
\text { - } & \text { Performance evaluation } \\
\end{array}$ \\
\hline & $\mathrm{D}$ & Yes & normal & $\begin{array}{ll}\text { - } & \text { Skills matrix } \\
\text { - } & \text { Tasks analysis } \\
\end{array}$ \\
\hline & $\mathrm{K}$ & No & normal & $\begin{array}{ll}\text { - } & \text { Training plan } \\
\text { - } & \text { Surveys } \\
\text { - } & \text { Tasks analysis } \\
\end{array}$ \\
\hline & $\mathrm{L}$ & No & poor & $\begin{array}{ll}\text { - } & \text { Need analysis of sme } \\
\text { - } & \text { Observation } \\
\text { - } & \text { Supervisor report } \\
\text { - } & \text { Critical incident analysis }\end{array}$ \\
\hline \multirow{4}{*}{ 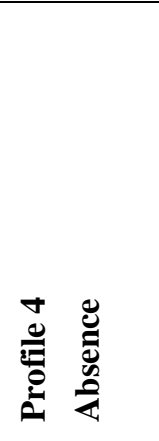 } & $\mathrm{P}$ & No & poor & $\begin{array}{ll}\text { - } & \text { Performance evaluation } \\
\text { - } & \text { Group discussion } \\
\text { - } & \text { Tasks analysis } \\
\end{array}$ \\
\hline & $\mathrm{G}$ & No & poor & - Performance evaluation \\
\hline & $\mathrm{N}$ & No & poor & $\begin{array}{ll}\text { - } & \text { Observation } \\
\text { - } & \text { Performance evaluation } \\
\end{array}$ \\
\hline & $\mathrm{B}$ & No & poor & $\begin{array}{ll}\text { - } & \text { Performance evaluation } \\
\text { - } & \text { Tasks analysis } \\
\end{array}$ \\
\hline
\end{tabular}

Training methods, problems faced and likely solutions through e-learning 
SMEs in Punjab region Pakistan use different training methods, they select methods rendering to their training needs and most of the time contingent on the suggestion of training that is available to them. Such methods comprise primarily lectures, conferences; learning by doing along with the computer based training (CBT) and the E-learning as presented in the table 3 .

Table 3. Training Methods engaged by SMEs

\begin{tabular}{|c|c|c|c|c|c|c|c|c|c|c|c|c|c|c|c|c|}
\hline \multirow{3}{*}{ Methods } & \multicolumn{16}{|c|}{ SMEs } \\
\hline & \multicolumn{4}{|c|}{$\begin{array}{l}\text { Profile } 1 \\
\text { Strong }\end{array}$} & \multicolumn{4}{|c|}{$\begin{array}{l}\text { Profile } 2 \\
\text { Average }\end{array}$} & \multicolumn{4}{|c|}{$\begin{array}{c}\text { Profile } 3 \\
\text { Weak }\end{array}$} & \multicolumn{4}{|c|}{$\begin{array}{c}\text { Profile } 4 \\
\text { Non-existent }\end{array}$} \\
\hline & $\mathbf{S}$ & I & $\mathbf{H}$ & $\mathbf{R}$ & $\mathbf{A}$ & $\mathbf{M}$ & $\mathbf{F}$ & $\mathbf{Z}$ & $\mathbf{O}$ & D & $\mathbf{K}$ & $\mathbf{L}$ & $\mathbf{P}$ & $\mathbf{G}$ & $\mathbf{N}$ & B \\
\hline \multicolumn{17}{|l|}{ Affirmative } \\
\hline \multirow{7}{*}{$\begin{array}{l}\text { Lecture } \\
\text { Seminar } \\
\text { Discussions } \\
\text { Job rotation } \\
\text { Coaching } \\
\text { Exercises } \\
\text { Presentation }\end{array}$} & $\mathrm{x}$ & $\mathrm{X}$ & $\mathrm{x}$ & $\mathrm{x}$ & $\mathrm{x}$ & $\mathrm{x}$ & $\mathrm{x}$ & $\mathrm{x}$ & $\mathrm{x}$ & $\mathrm{x}$ & $\mathrm{x}$ & $\mathrm{x}$ & $\mathrm{x}$ & $\mathrm{x}$ & $\mathrm{x}$ & $\mathrm{x}$ \\
\hline & $\mathbf{x}$ & $\mathbf{x}$ & $\mathbf{x}$ & $\mathbf{x}$ & & & $\mathbf{x}$ & & & $\mathbf{x}$ & & & & & & \\
\hline & $\mathbf{x}$ & $\mathbf{x}$ & & & & $\mathbf{x}$ & & $\mathbf{x}$ & & & & & & & $\mathbf{x}$ & \\
\hline & & & & & & & & & & & & & & & & \\
\hline & & & & & & & $\mathbf{x}$ & & $\mathbf{x}$ & $\mathbf{x}$ & $\mathbf{x}$ & & & & & \\
\hline & & & & $\mathbf{x}$ & $\mathbf{x}$ & $\mathbf{x}$ & & & $\mathbf{x}$ & $\mathbf{x}$ & & & & & & $\mathbf{x}$ \\
\hline & $\mathbf{x}$ & $\mathbf{x}$ & & & & $\mathbf{x}$ & & & & $\mathbf{x}$ & & & $\mathbf{x}$ & & & \\
\hline \multicolumn{17}{|l|}{ Interrogative } \\
\hline $\begin{array}{l}\text { Computer based } \\
\text { learning }(\mathrm{CBL})\end{array}$ & $\mathbf{x}$ & & & $\mathbf{x}$ & & & & & & $\mathbf{x}$ & & & & & & \\
\hline \multirow{4}{*}{$\begin{array}{l}\text { Active } \\
\text { Role playi } \\
\text { Case studi } \\
\text { e-learning }\end{array}$} & & & & & & & & & & & & & & & & \\
\hline & & $\mathbf{x}$ & & & & & & & & $\mathbf{x}$ & & & & & & \\
\hline & & $\mathbf{x}$ & & & & & & & & & & & & & & \\
\hline & $\mathbf{x}$ & $\mathbf{x}$ & $\mathbf{x}$ & $\mathbf{x}$ & $\mathbf{x}$ & & $\mathbf{x}$ & $\mathbf{x}$ & $\mathbf{x}$ & $\mathbf{x}$ & $\mathbf{x}$ & $\mathbf{x}$ & & & & \\
\hline $\begin{array}{l}\text { learning by } \\
\text { doing }\end{array}$ & $\mathbf{x}$ & $\mathbf{x}$ & $\mathbf{x}$ & $\mathbf{x}$ & $\mathbf{x}$ & $\mathbf{x}$ & $\mathbf{x}$ & $\mathbf{x}$ & $\mathbf{x}$ & $\mathbf{x}$ & & $\mathbf{x}$ & $\mathbf{x}$ & $\mathbf{x}$ & $\mathbf{x}$ & $\mathbf{x}$ \\
\hline
\end{tabular}

The Small and medium enterprises that make average or strong use, they employ e-Learning for all groups of employees. To this point: $<$ For all employees we use e-learning, the executive members as well as all other production workers $>$. SMEs with "weak" use of e-learning, only use e-learning for their executives, and interestingly such SMEs provide e-learning to those executive employee who has selected to enhance his/her understanding via e-learning.

The decision on e-learning use is also tied to their supposed gains of e-learning and the probability of this to resolve the problems faced by their organization. During interview CEO Aftab gives us the example, "employee select this method because he desired to continue functioning; he desires to work; he required to complete his master's degree while working at the same time". Table 4 contains all the perceived gains of e-learning by small and medium sized enterprises. 
Table 4. perceived gains of E-Learning and its probability to resolve problems of SMEs

\begin{tabular}{|c|c|c|c|c|c|c|c|c|c|c|c|c|c|c|c|c|}
\hline \multirow[t]{3}{*}{ Perceived Gains } & \multicolumn{16}{|c|}{ SMEs } \\
\hline & \multicolumn{4}{|c|}{$\begin{array}{c}\text { Profile } 1 \\
\text { Strong } \\
\end{array}$} & \multicolumn{4}{|c|}{$\begin{array}{l}\text { Profile } 2 \\
\text { Average }\end{array}$} & \multicolumn{4}{|c|}{$\begin{array}{c}\text { Profile } 3 \\
\text { Weak }\end{array}$} & \multicolumn{4}{|c|}{$\begin{array}{c}\text { Profile } 4 \\
\text { Non-existent }\end{array}$} \\
\hline & $\mathbf{S}$ & $\mathbf{I}$ & $\mathbf{H}$ & $\mathbf{R}$ & $\mathbf{A}$ & $\mathbf{M}$ & $\mathbf{F}$ & $\mathbf{Z}$ & $\mathbf{O}$ & D & $\mathbf{K}$ & $\mathbf{L}$ & $\mathbf{P}$ & $\mathbf{G}$ & $\mathbf{N}$ & B \\
\hline $\begin{array}{l}\text { Cost reductions of } \\
\text { training } \\
\text { (transportation, } \\
\text { meals, course, } \\
\text { lodging, time } \\
\text { saving) }\end{array}$ & $\mathrm{x}$ & $\mathrm{x}$ & & $\mathrm{x}$ & $\mathrm{x}$ & & $\mathrm{x}$ & $\mathrm{x}$ & $\mathrm{x}$ & $\mathrm{X}$ & $\mathrm{x}$ & $\mathrm{x}$ & $\mathrm{x}$ & $\mathrm{x}$ & $\mathrm{x}$ & \\
\hline Modularity & & & $\mathrm{x}$ & & & & $\mathrm{x}$ & & & $\mathrm{X}$ & $\mathrm{x}$ & & $\mathrm{x}$ & $\mathrm{x}$ & $\mathrm{x}$ & \\
\hline $\begin{array}{l}\text { Accessibility and } \\
\text { flexibility }\end{array}$ & $\mathrm{x}$ & $\mathrm{x}$ & $\mathrm{x}$ & $\mathrm{x}$ & & $\mathrm{x}$ & $\mathrm{x}$ & & $\mathrm{x}$ & $\mathrm{X}$ & & & $\mathrm{x}$ & & $\mathrm{x}$ & $\mathrm{x}$ \\
\hline Learning style & $\mathrm{x}$ & $\mathrm{x}$ & $\mathrm{x}$ & $\mathrm{x}$ & $\mathrm{x}$ & & & & & & & $\mathrm{x}$ & & & & \\
\hline Learning pace & & $\mathrm{x}$ & $\mathrm{x}$ & $\mathrm{x}$ & & $\mathrm{x}$ & & & $\mathrm{x}$ & $\mathrm{X}$ & & $\mathrm{x}$ & $\mathrm{x}$ & & & \\
\hline $\begin{array}{l}\text { Interactive } \\
\text { feedback }\end{array}$ & & & $\mathrm{x}$ & $\mathrm{x}$ & & & & $\mathrm{x}$ & & & & & $\mathrm{x}$ & & & \\
\hline $\begin{array}{l}\text { Literature } \\
\text { distribution }\end{array}$ & & & $\mathrm{x}$ & & & & & $\mathrm{x}$ & & & $\mathrm{x}$ & & & & & \\
\hline $\begin{array}{l}\text { Independence and } \\
\text { privacy }\end{array}$ & & $\mathrm{x}$ & & & & & & & & & $\mathrm{x}$ & & & & & \\
\hline Evaluation & $\mathrm{x}$ & $\mathrm{x}$ & $\mathrm{X}$ & $\mathrm{x}$ & & & & $\mathrm{X}$ & & & & & & & & \\
\hline \multicolumn{17}{|l|}{ Customization } \\
\hline Consistent delivery & $\mathrm{x}$ & $\mathrm{x}$ & $\mathrm{x}$ & & & & $\mathrm{x}$ & & & & $\mathrm{x}$ & & & & & \\
\hline $\begin{array}{l}\text { Empower to stay } \\
\text { competitive }\end{array}$ & $\mathrm{x}$ & $\mathrm{x}$ & $\mathrm{x}$ & $\mathrm{x}$ & $\mathrm{x}$ & $\mathrm{x}$ & $\mathrm{x}$ & & $\mathrm{x}$ & $\mathrm{X}$ & $\mathrm{x}$ & $\mathrm{x}$ & $\mathrm{x}$ & & $\mathrm{x}$ & $\mathrm{x}$ \\
\hline
\end{tabular}

It appears that the e-learning empowers SMEs in solving some of the hitches connected with the training. A great suppleness, a 24/7 accessibility, the probability to determine attained understanding and to function with unknown or novel materials, greater independence in the workroom, more confidentiality in the learning, greater alteration in the individual's desires and speed, a reduced time of training, a quick up gradation and training literature distribution, a faster training speed, reduction in transportation charges, work continuity, reduction in total training cost ( food, hotel, traveling, training), a steady course content delivery in comparison to teacher, probability of engraving learning and more easy evaluation of learning outcomes are all gains connected with the e-learning that empower to answer some of the problems of the training problems encountered by SMEs.

E-learning can also solve some of the problems faced in the training methods stage for instance giving admittance to training that would not be obtainable otherwise, a quicker upgrade of workforce, decrease of anxiety and uneasiness associated with the training, and none of the less gain access to quality courses. The SME workforce can also see that e-learning can answer some of their barriers, for instance e-learning empowers them to access various types of trainings and enhance their understanding and progress in their careers.

Training tools, problems faced and likely solutions through e-learning

In order to train employees SMEs use wide range of tools. All such tools are summarized in table 5 and are grouped in accordance to the four key categories of tools seen in literature, for 
instance auditory, visual, audiovisual and interactive tools.

Table 5. SME's Tools of Training

\begin{tabular}{|c|c|c|c|c|c|c|c|c|c|c|c|c|c|c|c|c|}
\hline \multirow[t]{3}{*}{ Tools } & \multicolumn{16}{|c|}{ SMEs } \\
\hline & \multicolumn{4}{|c|}{$\begin{array}{c}\text { Profile } 1 \\
\text { Strong }\end{array}$} & \multicolumn{4}{|c|}{$\begin{array}{l}\text { Profile } 2 \\
\text { Average }\end{array}$} & \multicolumn{4}{|c|}{$\begin{array}{c}\text { Profile } 3 \\
\text { Weak }\end{array}$} & \multicolumn{4}{|c|}{$\begin{array}{c}\text { Profile } 4 \\
\text { Non-existent }\end{array}$} \\
\hline & $\mathbf{S}$ & I & $\mathbf{H}$ & $\mathbf{R}$ & $\mathbf{A}$ & $\mathbf{M}$ & $\mathbf{F}$ & $\mathbf{Z}$ & $\mathbf{O}$ & D & $\mathbf{K}$ & $\mathbf{L}$ & $\mathbf{P}$ & $\mathbf{G}$ & $\mathbf{N}$ & $\mathbf{B}$ \\
\hline \multicolumn{17}{|l|}{ Visual tools } \\
\hline \multirow{5}{*}{$\begin{array}{l}\text { Lecture notes } \\
\text { Lecture notes } \\
\text { Black board } \\
\text { Overhead projector } \\
\text { Explicative } \\
\text { documents }\end{array}$} & & & & & & & & & & & & & & & & \\
\hline & $\mathrm{X}$ & $\mathrm{x}$ & $\mathrm{X}$ & $X$ & $\mathrm{x}$ & $\mathrm{x}$ & $\mathrm{x}$ & $\mathrm{x}$ & $\mathrm{x}$ & $\mathrm{x}$ & $\mathrm{x}$ & $\mathrm{x}$ & $\mathrm{x}$ & $\mathrm{x}$ & & $\mathrm{x}$ \\
\hline & $\mathrm{X}$ & $\mathrm{x}$ & $\mathrm{X}$ & $\mathrm{X}$ & $\mathrm{x}$ & $\mathrm{x}$ & $\mathrm{x}$ & $\mathrm{x}$ & $\mathrm{x}$ & $\mathrm{x}$ & $\mathrm{x}$ & $\mathrm{x}$ & $\mathrm{x}$ & $\mathrm{x}$ & & $\mathrm{x}$ \\
\hline & $\mathrm{X}$ & $\mathrm{x}$ & $\mathrm{X}$ & $X$ & $\mathrm{x}$ & $\mathrm{x}$ & $\mathrm{x}$ & $\mathrm{x}$ & $\mathrm{x}$ & $\mathrm{x}$ & $\mathrm{x}$ & $\mathrm{x}$ & $\mathrm{x}$ & $\mathrm{x}$ & & $\mathrm{x}$ \\
\hline & & & & & $\mathrm{x}$ & & & $\mathrm{x}$ & & $\mathrm{x}$ & $\mathrm{x}$ & & & $\mathrm{x}$ & & $\mathrm{x}$ \\
\hline \multicolumn{17}{|l|}{ Auditory tools } \\
\hline \multirow{2}{*}{\multicolumn{17}{|c|}{$\begin{array}{l}\text { Telephone } \\
\text { Tape recorder }\end{array}$}} \\
\hline & & & & & & & & & & & & & & & & \\
\hline \multicolumn{17}{|l|}{ Interactive tools } \\
\hline \multirow{5}{*}{$\begin{array}{l}\text { Multimedia } \\
\text { Computer } \\
\text { Courseware } \\
\text { Simulator } \\
\text { e-learning }\end{array}$} & $X$ & $\mathrm{x}$ & $\mathrm{x}$ & $X$ & $\mathrm{X}$ & $\mathrm{x}$ & $\mathrm{x}$ & $\mathrm{x}$ & $\mathrm{x}$ & $\mathrm{x}$ & $\mathrm{x}$ & $\mathrm{x}$ & & & & \\
\hline & $\mathrm{X}$ & $\mathrm{x}$ & $\mathrm{x}$ & $X$ & $\mathrm{X}$ & $\mathrm{x}$ & $\mathrm{x}$ & $\mathrm{x}$ & $\mathrm{x}$ & $\mathrm{x}$ & $\mathrm{x}$ & $\mathrm{x}$ & $\mathrm{x}$ & $\mathrm{x}$ & & $\mathrm{x}$ \\
\hline & & $\mathrm{x}$ & $\mathrm{X}$ & & & & & & & $\mathrm{X}$ & & & & & & \\
\hline & $X$ & & $\mathrm{X}$ & & & & & & & & & & & & & \\
\hline & $X$ & $\mathrm{X}$ & $\mathrm{x}$ & $\mathrm{X}$ & $\mathrm{X}$ & $\mathrm{x}$ & $\mathrm{X}$ & $\mathrm{X}$ & $\mathrm{X}$ & $\mathrm{x}$ & $\mathrm{X}$ & $\mathrm{x}$ & & & & \\
\hline \multirow{4}{*}{$\begin{array}{l}\text { Audio visual tools } \\
\text { Film (movie) } \\
\text { Slide show } \\
\text { Video tape recorder }\end{array}$} & & & & & & & & & & & & & & & & \\
\hline & $X$ & $\mathrm{X}$ & & & & & $\mathrm{x}$ & $\mathrm{X}$ & & & & & & & & \\
\hline & $X$ & $\mathrm{X}$ & $\mathrm{X}$ & $\mathrm{X}$ & $X$ & $\mathrm{X}$ & $\mathrm{X}$ & $\mathrm{X}$ & $\mathrm{X}$ & $\mathrm{x}$ & $\mathrm{x}$ & $\mathrm{x}$ & $\mathrm{X}$ & $\mathrm{X}$ & & $\mathrm{x}$ \\
\hline & $X$ & & & & $\mathrm{X}$ & & & & & $\mathrm{x}$ & $\mathrm{X}$ & & & & & \\
\hline
\end{tabular}

It is clear from the findings above that the tools employed by the SMEs are different and selected provisional to their requirements. The benchmarks used to choose training tools are wide-ranging and are diligently connected to the training method utilized. The ease of making available a training tool and employing that tool, expense of creation and employment of the tool, pursued learning objectives, level of trainer qualification, necessity to give training, the demand to train large number of employees in a short time period and to uniform the training content are some of the assortment standards for the SMEs tools of training.

There is no much change in the SMEs those are deploying e-learning and those who are not using e-learning in the choice of tools of training with the exclusion of the tools straight associated to e-learning, which are the multimedia tools.

Further, the auditory tools are employed inside other tools for instance power point slide shows. The interactive tools for instance, computers, simulators, courseware and multimedia; such tools are used by most of the SMEs, with the exemption of one, PowerPoint slide to train employee, many SMEs do not express computer as training tool when inquired what tools they are actually using in their enterprises, it is understood for them. The same situation happens for small enterprises that have some computers at their production area. Furthermore, Number of SMEs that is (12 out of 16) which deploy e-learning have primarily alternative to the interactive tools yet the visual, audio-visual and auditory in order to look up various senses of their workforce and to enhance their skills and learning. For this objective, Karim states; < $<$ In the two courses presently being established there must be sound, picture and 
interactive methods... to make sure that employees can prove their proficiency >>.

It appears that e-learning could resolve some of the hitches determined in the training tools stage. E-learning empowers small and medium enterprises to use a wide ranging training tools contained by the same course. SME owners/managers also find out that tools connected with the e-learning enable them to adjust themselves to the different learning styles of the employees and therefore to enhance their learning and productivity. One of the SME manager provides us with the example, saying; $<$ We got courses virtual, as our virtual courses on safety and health, all the production employees need to track and redo them sometimes in order to get certified. [...] they pick virtual courses and do them, courses comprised of photos, text, videos, sound and after finishing the course they need to do a test, the application monitors them and generates results to let them know if they did well or not. [.....] likewise we have some practical evaluations >>

\section{Evaluation, problems faced by SMEs and likely solutions through e-learning}

Small and medium enterprises of Punjab region of Pakistan evaluate outcomes of the training provided. Yet, the evaluation is prepared formally or informally in accordance to the training given and the working settings. Certainly, the labor union existence shakes the fact how evaluation is directed.

To evaluate the training there are many tools used by the SMEs. The selection of those tools along with the person and the time when evaluation is carried out is closely associated with the method of training used. The causes to assess are several and vary rendering to the SMEs. Mostly SMEs assess more than one stage of the Kirkpatrick's model of evaluation as presented in the table 6. The behavior stage (employee's deploy what they learned) is the stage the most assessed tailed by the reaction stage (stage of satisfaction in accordance with the training received). Those SMEs where e-learning is present they seem like more inclined to assess outcomes, at the last level (the results level) of model (Kirkpatrick evaluation model).

Table 6. Levels of Kirkpatrick model assessed by SMEs

\begin{tabular}{|c|c|c|c|c|c|c|c|c|c|c|c|c|c|c|c|c|}
\hline \multirow{3}{*}{ Phases } & \multicolumn{16}{|c|}{ SMEs } \\
\hline & \multicolumn{4}{|c|}{$\begin{array}{c}\text { Profile } 1 \\
\text { Strong }\end{array}$} & \multicolumn{4}{|c|}{$\begin{array}{l}\text { Profile } 2 \\
\text { Average }\end{array}$} & \multicolumn{4}{|c|}{$\begin{array}{c}\text { Profile } 3 \\
\text { Weak }\end{array}$} & \multicolumn{4}{|c|}{$\begin{array}{c}\text { Profile } 4 \\
\text { Non-existent }\end{array}$} \\
\hline & $\mathbf{S}$ & I & $\mathbf{H}$ & $\mathbf{R}$ & $\mathbf{A}$ & $\mathbf{M}$ & $\mathbf{F}$ & $\mathbf{Z}$ & $\mathbf{O}$ & D & $\mathbf{K}$ & $\mathbf{L}$ & $\mathbf{P}$ & G & $\mathbf{N}$ & B \\
\hline 1.Reaction & $\mathrm{X}$ & $\mathrm{x}$ & $\mathrm{x}$ & $\mathrm{x}$ & $\mathrm{x}$ & $\mathrm{x}$ & $\mathrm{x}$ & $\mathrm{x}$ & $\mathrm{x}$ & $\mathrm{x}$ & & $\mathrm{x}$ & $\mathrm{x}$ & & & $\mathrm{x}$ \\
\hline 2.Learning & $\mathrm{x}$ & $\mathrm{x}$ & $\mathrm{x}$ & $\mathrm{x}$ & $\mathrm{x}$ & & $\mathrm{x}$ & $\mathrm{x}$ & $\mathrm{x}$ & $\mathrm{x}$ & $\mathrm{x}$ & $\mathrm{x}$ & $\mathrm{x}$ & & & $\mathrm{x}$ \\
\hline 3.Behavior & $\mathrm{x}$ & $\mathrm{x}$ & $\mathrm{x}$ & $\mathrm{x}$ & $\mathrm{x}$ & $\mathrm{x}$ & $\mathrm{x}$ & $\mathrm{x}$ & $\mathrm{x}$ & $\mathrm{x}$ & $\mathrm{x}$ & $\mathrm{x}$ & $\mathrm{x}$ & $\mathrm{x}$ & $\mathrm{x}$ & $\mathrm{x}$ \\
\hline 4.Results & $\mathrm{X}$ & $\mathrm{x}$ & $\mathrm{x}$ & $\mathrm{x}$ & $\mathrm{x}$ & & & & $\mathrm{X}$ & $\mathrm{X}$ & & & $\mathrm{x}$ & & & $\mathrm{x}$ \\
\hline
\end{tabular}

It appears that e-learning could also answer some of the hitches investigated during the 
training assessment stage. As company owner Aftab comments: $<<$ Training through computers speaks by itself, whether the person reached or didn't reach the ends $>>$.

E-Learning also empowers workforce to retake the course contents or some portion of the course according to their desires when the demand arises and re-examine their understanding and the knowledge. It also helps SMEs to adapt the training to the particular needs of the working employees and to identify level of understanding of learners about the enclosed material and this can be done within any time of the course. CEO Asad provides us an example when he stats: Our enterprise have different courses online, for instance [....], arriving to end of each course employees needs to go for a test, the application assess them and lets them informed if they achieved or not. They do a test at the end of every module and employees need to get it pass in order to go along the next module >>.

E-learning eases the training evaluation at various levels of the Kirkpatrick's evaluation model (1996), particularly the second level namely "what was learned" and the level third the use" and the last "the results level" by linking the outcomes of e-learning with the supplementary applications. E-learning also assists in an unbiased and more persistent evaluation. Moreover, the e-learning enables to see who has obtained training and at what time. It also facilitates to make sure that every learner received the uniform content as stated by the manger Aftab: $<$ We have a learning management system LMS). Computers permit us to confirm that everyone obtained the similar training $>>$.

\section{SMEs Economic Performance and Productivity through E-learning}

Generally, the SMEs have pretty good understanding of how e-learning can assist their enterprises become more competitive and productive than the traditional training. SME owners-mangers are very much aware of the fact that they can diminish their training costs and time through e-learning, as well as e-learning can give them more suppleness and availability allowing their businesses more advance, productive and competitive. The interview also appears to mention that e-learning enhances the ability of enduring competitiveness irrespective the level of application of e-learning by the SMEs as presented in table7.

Table 7. Impact on Economic performance and productivity of SMEs

\begin{tabular}{|c|c|c|c|c|c|c|c|c|c|c|c|c|c|c|c|c|}
\hline Determining factors of & \multicolumn{16}{|c|}{ SMEs } \\
\hline $\begin{array}{l}\text { E-learning relevant to } \\
\text { the }\end{array}$ & \multicolumn{4}{|c|}{$\begin{array}{l}\text { Profile } 1 \\
\text { Strong }\end{array}$} & \multicolumn{4}{|c|}{$\begin{array}{l}\text { Profile } 2 \\
\text { Average }\end{array}$} & \multicolumn{4}{|c|}{$\begin{array}{c}\text { Profile } 3 \\
\text { Weak }\end{array}$} & \multicolumn{4}{|c|}{$\begin{array}{c}\text { Profile } 4 \\
\text { Non-existent }\end{array}$} \\
\hline performance & $\mathbf{S}$ & I & $\mathbf{H}$ & $\mathbf{R}$ & $\mathbf{A}$ & $\mathbf{M}$ & $\mathbf{F}$ & $\mathbf{Z}$ & $\mathbf{O}$ & D & $\mathbf{K}$ & $\mathbf{L}$ & $\mathbf{P}$ & $\mathbf{G}$ & $\mathbf{N}$ & B \\
\hline Understanding increase & $\mathrm{x}$ & $\mathrm{x}$ & $\mathrm{x}$ & $\mathrm{x}$ & $\mathrm{x}$ & $\mathrm{x}$ & $\mathrm{x}$ & $\mathrm{x}$ & $\mathrm{x}$ & $\mathrm{x}$ & $\mathrm{x}$ & $\mathrm{x}$ & $\mathrm{x}$ & $\mathrm{x}$ & $\mathrm{x}$ & $\mathrm{x}$ \\
\hline $\begin{array}{l}\text { Enable to remain } \\
\text { competitive }\end{array}$ & $\mathrm{x}$ & $\mathrm{x}$ & $\mathrm{x}$ & $\mathrm{x}$ & $\mathrm{x}$ & $\mathrm{x}$ & $\mathrm{x}$ & $\mathrm{x}$ & $\mathrm{x}$ & $\mathrm{x}$ & $\mathrm{x}$ & $\mathrm{x}$ & $\mathrm{x}$ & $\mathrm{x}$ & $\mathrm{x}$ & $\mathrm{x}$ \\
\hline
\end{tabular}




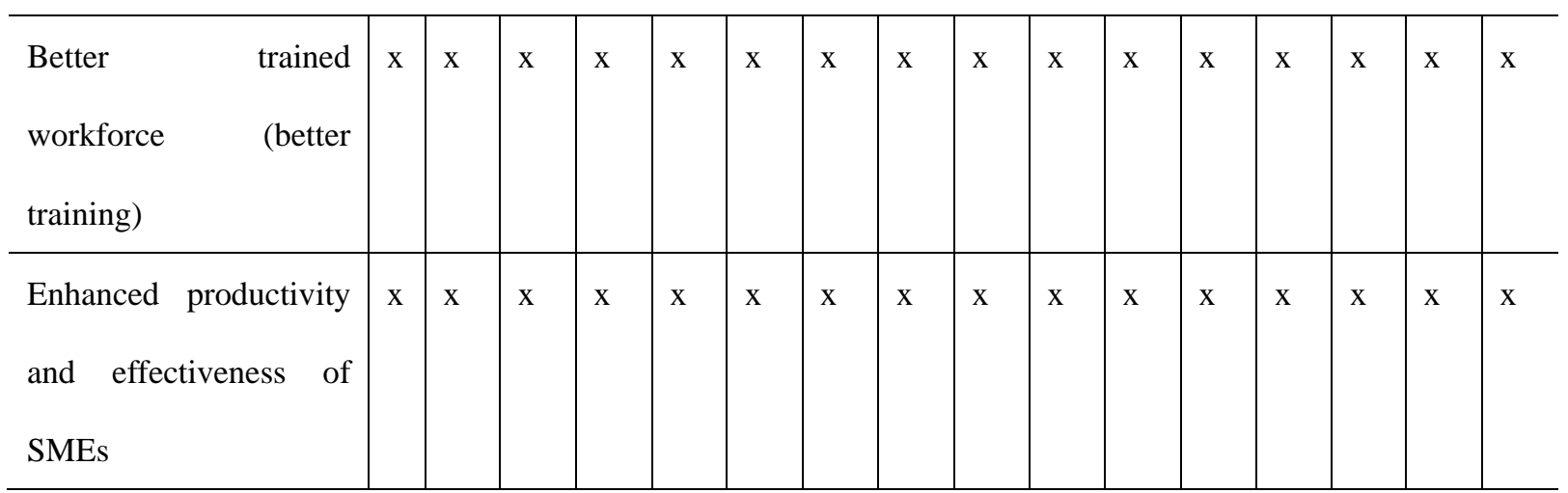

There is no much variance among the SME those are using e-learning and those who are not using it at all concerning the discernment on how e-learning can put positive influence on the productivity and economic performance of their enterprises (table 7). Some key items stated by the SMEs intention in the direction of formative factors revealed in the literature in order to enhance performance and advancement. They have confidence in that e-learning gives them opportunity of having well trained workforce and after completing training they can better equip to undertake their jobs. For this perseverance, one of SME manager Karim comments; $<$ In two of the modules presently being established there must be sound, picture, interactivity... to make sure that employees can prove their proficiency >>. Further some of the SMEs commented on the fact that e-learning provides their employees ability to advance their understanding. For instance one of SME's CEO gives really good example, mentioning that: "Some of the employees have selected e-learning to advance their work understanding and it was proposed by the workers not by the owner-manager."

SMEs also have faith in that having more trained employees enhances the competitiveness and productivity of the enterprises and has a positive influence on the economic performance of the businesses. Thus, it appears that, grounded on the case study, e-learning backs to the economic progress of small and medium enterprises. The findings of the case study mention that e-learning appears to assist SMEs in becoming more advance, productive and competitive.

\section{Conclusion}

The study indicates that the SME's process of training comprises of the same steps as for the large organizations and companies. It contains the training need analysis, the choice and applications of training tools and methods along with the training evaluation.

Training need analysis of all the SMEs participated in the study verifies that what diverges from one SME to another is the only level of discipline and formalization with which they done analysis and degree of sophistication with which they used training tools. E-learning empowers SMEs to assess, when hiring or pretty early in the process of training, the needs of training of the employees and to answer the problems identified at the proper moment and thus, ensure the realization of enterprise's goals.

The causes that stimulate SMEs to employ e-Learning in that stage of the training process is the necessity to assess, when to hire or pretty start of the process of training, the training 
requirements of their workforce. Moreover, SMEs also employ e-learning to make sure the realization of their company's goals.

SMEs in the Punjab region of Pakistan use wide ranging methods of training. They believe that e-learning empowers them to answer some of the hitches connected with the training. A great suppleness, a 24/7 accessibility, the probability to determine attained understanding and to function with unknown or novel materials, greater independence in the workroom, more privacy in learning, greater adaptation to the individual's desires and speed, a reduced time of training, a quick up gradation and training literature distribution, a faster training speed, reduction in transportation charges, work continuity, reduction in total training cost ( meals, hotel, travel, training), a consistent course content delivery in comparison to teacher, probability of engraving learning and more easy evaluation of learning outcomes are all gains connected with the e-learning that empower to answer some of the problems of the training problems encountered by SMEs.

SME owners-mangers are very much aware of the fact that they can diminish their training costs and time through e-learning, as well as e-learning can give them more suppleness and availability allowing their businesses more advance, productive and competitive. Therefore, it appears that, based on the case study, e-learning empowers SMEs to enhance their productivity and economic performance.

\section{References}

Bassi, L. J., \& Van Buren, M. E. (1999a). Sharpening the leading edge. Training \& Development, 53(1), 23-33.

Bassi, L. J., \& Van Buren, M. E. (1999b). The 1999 ASTD state of the industry report. Training \& Development, 53(2), 3-27.

Beamish, N., Armistead, C., Watkinson, M., \& Armfield, G. (2002). The deployment of e-learning in UK/European corporate organisations, European Business Journal, 14(3), 105-115.

Brown, J. (2002). Training needs assessment: A must for developing an effective training program. Public Personnel Management, 31(4), 569-578. https://doi.org/10.1177/009102600203100412

Cook, S. (2005a). Learning needs analysis: Part 1: What is learning needs analysis? Training Journal, January, 64-68.

Daelen, M., Miyata, C., Op de Beeck, I., Schmitz, P. E., van den Branden, J., \& Van Petegem, W. (2005). E-learning in continuing vocational training, particularly at the workplace, with emphasis on Small and Medium Enterprises, Final report (EAC-REP-003), European Commission.

Elbadri, A. N. A. (2001). Training practices of polish companies: An appraisal and agenda for improvement. Journal of European Industrial Training, 25(2/3/4), 69-79. https://doi.org/10.1108/EUM0000000005438 


\section{Ml Macrothink}

Journal of Public Administration and Governance

ISSN 2161-7104

2018, Vol. 8, No. 4

Fry, K. (2001). E-learning markets and providers: some issues and prospects. Education \& Training, 43(4/5), 233-239. https://doi.org/10.1108/EUM0000000005484

Garavaglia, P. L. (1993). How to ensure transfer of training. Training \& Development, 47(10), 63-68. ICELW 2012 June 13th -15th, New York, NY, USA

Hall, B., \& LeCavalier, J. (2000). E-Learning across the enterprise: the benchmarking study of best practices, Sunnyvale, California: brandon-hall.com.

Hussain, J. G. et. al. (2007). Black and minority ethnic graduate entrepreneurs: Motivations, characteristics and access to finance, Institute of small business and entrepreneurship conference (ISBE), Glasgow, November 2007. ISBE

Kotey, B., \& Sheridan, A. (2004). Changing HMR practices with firm growth. Journal of Small Business and Enterprise Development, 11(4), 474-485. https://doi.org/10.1108/14626000410567125

Laflamme, R. (1999). La formation en entreprise: nécessité ou contrainte? Québec: Les Presses de l'Université Laval.

Mayo, G. D., \& Dubois, P. H. (1987). The complete book of training: Theory, principles and techniques. San Diego, CA: University Associates Inc.

Miles, M. B., \& Huberman, A. M. (1994). Qualitative Data Analysis: An Expanded Sourcebook, 2nd Edition, Thousand Oaks, California: Sage Publications.

Misko, J., Choi, J., Hong, S.Y., \& Lee, I. S. (2004). E-learning in Australia and Korea: Learning from practice, Seoul: Korea Research Institute for Vocational Education \& Training.

Mittelstaedt, J. D., Harben, G. N., \& Ward, W. A. (2003). How small is too small? Firm size as a barrier to exporting from the United States, Journal of Small Business Management, $41(1), 68-84$.

Sadler-Smith, E., Sargeant, A., \& Dawson, A. (1998). Higher level skills training and SMEs. International Small Business Journal, $16(2), \quad$ 84-94. https://doi.org/10.1177/0266242698162005

Servage, L. (2005). Strategizing for workplace e-Learning: Some critical considerations", Journal of Workplace Learning, 304-317. https://doi.org/10.1108/13665620510606733

SMEDA Pakistan, (2010). Retrieved from http://www.smeda.org.pk/main (Aug 20, 2010) SMEDA, Developing SME Policy in Pakistan.

Smith, A., \& Hayton, G. (1999). What drives enterprise training? Evidence from Australia. The International Journal of Human Resource Management, 10(2), 251-272. https://doi.org/10.1080/095851999340549 


\section{Macrothink}

Journal of Public Administration and Governance ISSN 2161-7104 2018, Vol. 8, No. 4

Tanova, C., \& Nadiri, H. (2005). Recruitment and training policies and practices: The case of Turkey as an EU candidate. Journal of European Industrial Training, 29(8/9), 694-711. https://doi.org/10.1108/03090590510629830

Tyler, K. (1999). Brushing up on the three R's. HRMagazine, 44(10), 82-88.

Yin, R. K. (1994), Case study research: Design and methods, 2nd Edition, Thousand Oaks, California: Sage Publications.

\section{Copyright Disclaimer}

Copyright for this article is retained by the author(s), with first publication rights granted to the journal.

This is an open-access article distributed under the terms and conditions of the Creative Commons Attribution license (http://creativecommons.org/licenses/by/4.0/). 